\title{
Linking bank advertising to customer attitudes: The role of cognitive and affective trust
}

\author{
Nursultan Bilisbekov ${ }^{a}$, Christian Sarfo ${ }^{b^{*}}$, Ala' Omar Dandis $^{c^{*}}$ and Mohammad Al-Haj Eid $^{\text {b }}$
}

${ }^{a}$ Gachon University, south Korea

${ }^{b}$ University of Otago, New Zealand

${ }^{c}$ Assistant Professor of Marketing, Department of Marketing, Applied Science Private University, Amman, Jordan

${ }^{d}$ University of Otago, Dunedin, New Zealand

\section{H R O N I C L E}

\section{Article history:}

Received: August 10, 2020

Received in revised format:

November 152020

Accepted: November 27, 2020

Available online:

November 27, 2020

Keywords:

Cognitive trust

Affective trust

Attitude

Future interaction

Uncertainty

Bank advertising

\section{A B S T R A C T}

The main objective of this paper is to investigate the effect of affective and cognitive trust in bank advertising toward its potential customers. An advertising experiment was conducted by creating two bank advertisements focusing on affective and cognitive trust in bank advertising. SEM analysis is conducted with a sample of 254 customers who banked with the Central Bank of Ghana using STATA 14.1. Results showed that customers of a bank are more drawn to affective advertising than cognitive advertising. Results also showed that cognitive trust is a stronger predictor of anticipation towards future interactions with a bank than affective trust. Uncertainty and commitment had insignificant relationships with affective trust. Cognitive trust had a positive relationship with commitment, while affective trust had no significant relationship with commitment. Managerial implications and future research of the findings are discussed.

\section{Introduction}

"Trust is like the air we breathe -- when it is present, nobody really notices. When it's absent, everyone notices" — Warren Buffett. Trust remains the cornerstone for a customer to have good relations with their bank and to be satisfied with the services provided (Sundin \& Nordin, 2013). A good client-company relationship is built upon trust (Wälti, 2012). Accordingly, previous research has identified how customer trust can be achieved through product value (Lantieri \& Chiagouris, 2009), authentic transparency (Miranda \& Klement, 2009), being realistic with customers (Smyth, Gustafsson, \& Ganskau, 2010), understanding the business customer base (Hultén, 2007), being respectful (Gill, Flaschner, \& Shachar, 2006), and keeping promises (van Esterik-Plasmeijer \& van Raaij, 2017).

The deregulation of the financial markets led to relaxed monetary policies and the absolute power wielded by these financial institutions (Uslaner, 2010). What ensued was a lack of transparency within the financial markets, a factor which is crucial in market freedoms. For instance, Guiso (2010) concluded that bankers are less trusted than the average person. Interestingly his research noted that banks themselves were more trusted than the bankers who work for them, indicating that there was not a complete loss of trust in the financial sector. The 2008 financial crisis further compounded this issue and led to a decline in general trust and confidence in financial institutions (Sapienza \& Zingales, 2012).

\footnotetext{
* Corresponding author

E-mail address: A dandis@asu.edu.jo (A. O. Dandis) 
In Ghana, major financial reforms including the privatisation of some state owned banks and liberalization of the financial sector led to an influx of many new and foreign banks, intensified competition and reduced profit margins for banks with increased access to loans for the Ghanaian populace (PricewaterhouseCoopers, 2009). Unfortunately, the liberalization also led to the proliferation of a microfinance sector which was poorly regulated leading to high incidents of fraud and insolvency (World, 2017).

Customers lost millions of Ghana Cedis in investment as a result of several microfinance companies being insolvent. As a response to this crisis, the Ghana Parliament passed into law the Deposit Protection Bill to protect depositors when a bank goes bankrupt (Opoku, 2016). In addition, the collapse of several major banks in 2017 and 2018 (Kosiba, Boateng, Okoe, \& Hinson, 2018) and the Bank of Ghana revoking the licences of 347 microfinance institutions in 2019 for insolvency (Darfah, 2019) heightened customer concerns about financial institutions. The current situation underscores the need for banks not only to restore the trust of customers but also to differentiate themselves from other institution. Ennew and Sekhon (2007) examined trust within the financial services and defined trust as "an individual's willingness to accept vulnerability on the grounds of positive expectations about intentions or behavior of another in a situation characterized by interdependence and risk." (p. 63). Trust can serve as a buffer against customers' negative experiences (van Esterik-Plasmeijer \& van Raaij, 2017). That is, when there is trust, a customer is more willing to overlook a negative experience as an exception but when there is lack of trust, a negative experience is perceived as evidence that a bank cannot be trusted. Advertising is one of the main marketing tools used to foster consumer trust (Bachnik \& Nowacki, 2018). In Ghana, Amoako, Anabila, Effah, and Kumi (2017) contend that banks employ aggressive advertising to highlight differences in their products and services to influence client attitudes and behaviours in favour of their brands.

The aim of this study is to expand on previous research on trust in the banking industry by examining how advertising can evoke customer trust. Although many studies test the role of trust in marketing in general (e.g., Rajavi, Kushwaha, \& Steenkamp, 2019; van Esterik-Plasmeijer \& van Raaij, 2017), no studies are available which empirically tested the role of affective and cognitive trust in bank advertising. In an attempt to address this gap in the literature, we focus on cognitive and affective trust in the Ghana banking advertising. We subsequently investigate how trust influence customers' attitudes towards the banks. This is achieved by collecting and analysing quantitative data from an experimental advertising study. The conceptual framework for the study is presented with Fig. 1.

The following section examines the literature and explores the rationale linking the study variables. We then describe the sample and data collection procedures. We present the study results including descriptive statistics, the convergent and discriminant validity of the measurement model and the structural equation modelling (SEM) analysis. We discuss the theoretical and practical implications and end with the limitations and directions for future research.

\section{Theoretical Background}

\subsection{Advertising}

Advertising is a powerful tool and an integral part of modern business strategies to capture and retain market share for within a given market. Advances in technology have created an ever more diverse advertising tools to gain the attention, mood, and imagination of targeted audiences making a single definition for advertising difficult (Pickton \& Broderick, 2005). Fundamentally however, advertising comprises the creation and mass media distribution of messages to persuade a targeted audience from profit seeking suppliers by or on behalf of brand marketers (Schultz, 2016). Advertising messages are crafted to accomplish four main utilities: (1) to create beliefs about brands for customers (brand building); (2) to gain attention of persons interested in buying; (3) to increase buying of a product (driving purchase); and (4) to influence change in behaviour (Thorson \& Rodgers, 2012). Due to the ever evolving nature of the key element of the advertising process - customers - , advertising is constantly revolving, adapting, and reinventing (Schultz, 2016). Studies suggest that advertising affects attitudes through a sequential three-stage process involving thinking (cognitive processes), feeling (affective processes), and doing (conative processes) (Pickton \& Broderick, 2005). Within the financial sector, banks tend to allocate a substantial portion of their budget to advertising expenses (Acar \& Temiz, 2017).

\subsection{Trust Theory}

Trust theory in the business sector emerged as an expectation that the actions of businesses must benefit customers and society rather than just themselves (Gambetta, 1988). Researchers contend that there are two dimensions of trust in business: rational and emotional (Dowell, Morrison, \& Heffernan, 2015; Parayitam \& Dooley, 2009). The rational dimension of trust indicates the belief that the object of trust can fulfil its obligations. It is based on an assessment of competence, the effectiveness of work, and consistency and predictability of actions. These dimensions draw from the work of McAllister (1995) who considered trust to be made up of two components: the affective and cognitive components. He considered the affective parts of trust to include emotional assessment of interactions, emotions concerning an object and situations whiles the cognitive component consists of the evaluation of the experience of an interaction and expectations regarding the outcome of the interaction.

\subsection{Cognitive and affective trust appeal}

Trust can be based on a rational, cognitive evaluation of performance or based on emotional, affective response (Erdem \& Ozen, 2003). Researchers agree that both cognition-based trust and affect-based trust should be considered as separate 
constructs, as they each can have different antecedents (Erdem \& Ozen, 2003; Johnson \& Grayson, 2005). Affective trust is characterized by feelings of security and the perceived strength of a relationship (B.-C. Ha, Park, \& Cho, 2011). Affective trust shows that the parties involved have some emotional bond that has generated from the initial business relation and resulted in the concern for the other party over and above self-interest (Akrout, Diallo, Akrout, \& Chandon, 2016). Cognitive trust, conversely, is the degree of confidence or willingness that exists in order to depend on another party's reliability and competence (Sharif, Kalafatis, \& Samouel, 2005). This form of trust is performance-based, and rationality is used as the basis for trusting the other party. Akrout et al. (2016) pointed out that a seller's reputation in a business relationship is hence based on assessments of fairness and honesty.

\subsection{Trust and Attitude towards Banks}

Consumers' attitude informs their trust in products and subsequently in the company (V. Ha, 2020) and vice versa. Similarly, attitude positively impact the intention of customers to use digital banking service (Nguyen, 2020). Trust affects customer's attitude towards buying (Alsajjan \& Dennis, 2010) and using (Flavián, Guinalíu, \& Gurrea, 2006) buying a product. For example, trust is considered an influencing factor in determining whether a customer will adopt a product, e.g. mobile app products (Kaushik, Mohan, \& Kumar, 2020). Extant literature on trust has long established the link between consumer trust and their attitude towards adopting new products and services (Gefen, Karahanna, \& Straub, 2003; Macintosh \& Lockshin, 1997). Previous studies have shown that when emotional connections deepen, trust in a partner will progress beyond what is justified by the available cognitive trust (Akrout et al., 2016). Furthermore, affective trust, which is emotion-driven, makes the relationship less transparent to cognitive risk assessments (Ha et al., 2011). Johnson and Grayson (2005) postulated that the essence of affective trust is reliance on a partner, based on emotions. This form of trust is subjective, as the perceived trustworthiness of one party is based on the feelings, emotions, and moods of the other (Hansen, Morrow Jr, \& Batista, 2002). Individuals and businesses in a corporate entity when assessing trustworthiness often consider the history of a partner organisation and scrutinise how that particular organisation has handled certain situations (Rajavi et al., 2019). For cognitive trust to be formed, the seller must believe the buyer has an acceptable reputation and meets the purpose that the seller has outlined regarding a good reputation (Sharif et al., 2005). Institutions that are perceived to be fair are more likely to be cognitively trusted than those that strictly foster their interests (Akrout et al., 2016), and thus we hypothesise that:

\section{$\mathrm{H}_{1}$ : Affective trust positively influences attitude toward the bank.}

$\mathrm{H}_{2}$ : Cognitive trust positively influences attitude toward the bank.

\subsection{Commitment}

Drawing on the relationship marketing literature, theorised that trust and commitment are theorised as critical constructs in fruitful relational exchanges (Morgan \& Hunt, 1994). Furthermore, the literature emphasis that trust and commitment are central intermediate constructs in the latent structure models of components and evaluations of customers who have a high relational or partnering orientation toward an organisation (Dowell et al., 2015). Dowell et al. (2015) equally argued that commitment involves potential vulnerability and sacrifice, and follows that people are unlikely to be committed unless trust is established. Thus, this explains that significant relationships between affective and cognitive trust and the sense of obligation represented by normative commitment (Erkmen \& Hancer, 2015). When developing affective trust for a product, service or organisation, the mutual investments in a relationship, by both organisation and consumer, can generate the sort of trust that encourages obligation (Erdem \& Ozen, 2003) by the both parties. Thus, affective trust can engender the felt need of consumers to open an account in the bank, leading to a somewhat insignificant relationship between affective trust and commitment, because, at the initial stages, the commitment of customers was more dependent on cognitive variance (Mukherjee \& Nath, 2003). Regarding cognitive trust, Erdem and Ozen (2003) argue that an authority that provides services like advice, aid, or assistance signals that they are dependable and reliable, thus making the discharging of their obligations more conventional.

Previous studies have reported differing relationships between both affective and cognitive trusts and commitment. For example, Casalo, Flavián, and Guinalíu (2007) report a weak significant relationship between affective trust and commitment, and a strong significant relationships cognitive trust and commitment. On the contrary, Colquitt, LePine, Piccolo, Zapata, and Rich (2012) show significant relationship between cognitive trust and commitment but no significant relation of affective trust and commitment, describing it in way that affective trust is built on the foundation of cognitive trust. To test our view on this, we hypothesise thus:

$\mathrm{H}_{3}$ : Affective trust has an insignificant influence on commitment to a bank.

$\mathrm{H}_{4}$ : Cognitive trust positively influences commitment to a bank.

\subsection{Uncertainty}

Marketing channels literature has long established that uncertainty is the extent to which a partner has enough information to make critical decisions, predict the consequences of those decisions, and have confidence in those decisions (Banks, Hutchinson, \& Meyer, 2002). Yang, Mossholder, and Peng (2009) argued in their study on supervisory effects that trust decreases a partner's decision-making uncertainty because the trusting partner has confidence that a trustworthy party can be relied on. Decreasing uncertainty is very important as it also increases a partner's reliability (McCole, Ramsey, \& Williams, 
2010). Colquitt et al. (2012) in their study on job performance, concluded that cognitive trust was negatively related to uncertainty, but there was no strong correlation of affective trust to uncertainty. They highlighted that building emotional bonds could not show immediate long-term stability and significantly decrease uncertainty. That leads us to question whether the relationship between affective trust and uncertainty is significant. Consequently, we hypothesise:

H5: Affective trust negatively influences uncertainty.

H6: Cognitive trust negatively influences uncertainty.

\subsection{Anticipation of future interaction}

Studies, for example, Insko et al. (2001), have argued that the anticipated future interaction may reduce among groups and not among individuals because of the likelihood of a higher trust index at the individual level than the group . Colquitt et al. (2012) then concluded that affective trust is associated with commitment to reciprocate, and cognitive trust is associated with reducing the uncertainty of future interactions. Similarly, cognitive trust and affective trust contribute significantly to a customer's willingness to meet with a service provider in the future, reporting a cognitive trust coefficient higher than that of affective trust (Johnson \& Grayson, 2005). Therefore, we consider that affective trust and cognitive trust will have a positive relationship with anticipation of future banking interaction, and thus hypothesise:

$H_{7}$ : Affective trust positively influences future interaction expectations.

$H_{8}$ : Does cognitive trust positively influence future interaction expectations.

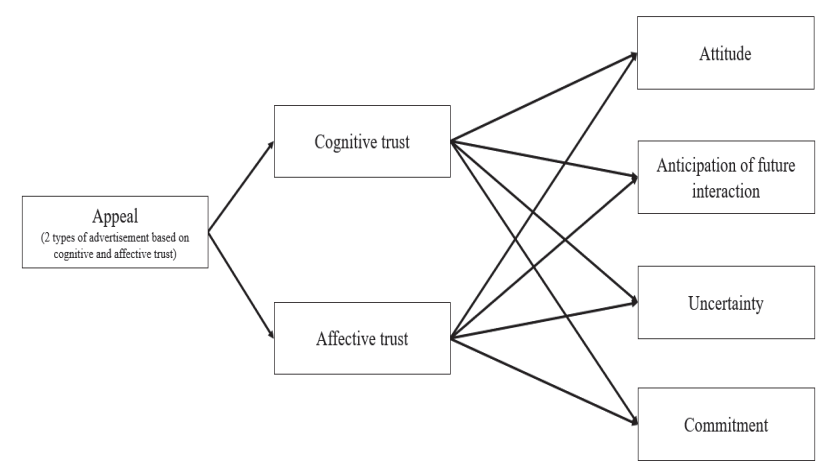

\section{Methodology}

Fig. 1. Research model and hypotheses

\subsection{Sample and Data collection}

Previously evaluated survey instruments were used in the study. Paper \& pencil self-administered surveys were used to collect data from respondents because it has been found to produce a higher response rate than online or telephone surveys in developing economies, and assures respondents of anonymity (Eckford \& Barnett, 2016). The survey was distributed to only individuals who banked with Bank of Ghana (BoG) (the central bank of Ghana). Customers of the BoG were selected because BoG is considered the most stable financial institution in Ghana (Huq \& Tribe, 2018). In order to ensure participants did not base their judgments on extraneous factors influencing their banking patterns other than advertising, a fictitious ad was used for the experiment (Howard \& Kerin, 2004). A pilot test was conducted to ensure clarity of the questionnaire. The survey was pretested with a small sample of academic professionals, the staff of BoG and customers of BoG, who were not included in the final analysis. Permission to gather data from the various bank branches was sought through the BoG branch HR managers via mail. A total of 56 branches out of 184 branches based throughout Ghana approved. Final copies of the questionnaire were sent to managers for distribution to customers whose participation in the study was voluntary, and customers assured that their participation would be anonymous. We received a total of 296 responses; some were omitted due to significant missing data on fundamental constructs, leaving a final sample of 254 usable responses for the study. 49.21\% ( $n=125)$ participants answering for 'Affective advertisement" and 50.79\% $(\mathrm{n}=129)$ students for 'Cognitive Advertisement'. Female respondents were $46.46 \%(\mathrm{n}=118)$ whiles $53.54(\mathrm{n}=136)$ were male respondents.

\subsection{Questionnaire and measurements}

The questionnaire was conducted to ask participants the perception of two different types of bank advertisements. One of them stands for affective trust and designed to raise affective trust in participants by highlighting the bank's policy on care and concern to customers (see Figure 2). The $2^{\text {nd }}$ ad was for cognitive trust, highlighting professionalism and credibility (see Figure 3). The selection of the various groups was through simple random sampling. Each group was exposed to a different advertisement. Each group was shown the same background picture with different advertisement messages emphasising 
affective trust or cognitive trust as well as customer review displaying each bank's approach to attract consumers and their marketing strategies. We expected that messages of care and concern would raise emotional bond and engender affection as opposed to the message of competence, ability, and credibility and long history that raised the participants' perception of the bank's cognitive skills. The questionnaire used Likert scale responses ranging from highly disagree to highly agree using a numerical score between 1 = "strongly disagree" to 5 = "strongly agree." (Cooper \& Schindler, 2003).

Following prior studies, measures of trust were taken from previously validated research of (Akrout et al., 2016; Grayson, Johnson, \& Chen, 2008) consisting of a 3-item scale each of cognitive and affective trust. Drawing on prior research, anticipation of future interactions was measured using a 3-item scales from Colquitt et al. (2012); Johnson and Grayson (2005). Attitude toward the advertised bank was a 3-item scale suggested by Akrout et al. (2016) and Rajavi et al. (2019). The 3-item scale measures of commitment were adapted from Colquitt et al. (2012). Measures of uncertainty were adapted from Colquitt et al. (2012) and Banks et al. (2002). Uncertainty was represented with following 4-item scale questions. For manipulation check of cognitive and affective persuasion appeal, measures by Drolet and Aaker (2002) was adopted.

Table 1

Measurement models

\begin{tabular}{|c|c|}
\hline & Factor loading \\
\hline \multicolumn{2}{|l|}{ Attitude toward bank $(\alpha=.869, \mathrm{CR}=.92, \mathrm{AVE}=.743)$} \\
\hline I feel that this bank is good to work with & 0.955 \\
\hline I like banks attitude to clients & 0.902 \\
\hline I am willing to open an account in the presented bank & 0.669 \\
\hline \multicolumn{2}{|l|}{ Anticipation of future interactions $(\alpha=.682, \mathrm{CR}=.87, \mathrm{AVE}=.678)$} \\
\hline I think it is safe to keep money with the bank & 0.822 \\
\hline I would feel comfortable to do business with this bank. & 0.883 \\
\hline I will rely on this bank if I need to manage my future investments & 0.894 \\
\hline \multicolumn{2}{|l|}{ Affect-based trust $(\alpha=.890, \mathrm{CR}=.93, \mathrm{AVE}=.577)$} \\
\hline I feel like this bank, in general, will concern about my needs and feelings. & 0.940 \\
\hline I think bank employees of this bank will respond constructively and caringly. & 0.799 \\
\hline I feel strong ties towards this bank & 0.760 \\
\hline \multicolumn{2}{|l|}{ Cognition-based trust $(\alpha=.781, \mathrm{CR}=.88, \mathrm{AVE}=.605)$} \\
\hline I think this bank will be competent to handle my money with professionalism and dedication. & 0.756 \\
\hline I think they are competent for the job. & 0.802 \\
\hline I think they are professional and dedicated. & 0.834 \\
\hline \multicolumn{2}{|c|}{ Imagine that you are a current client of this bank. One day, you get to know that another bank is quite compelling yet similar to this bank) } \\
\hline \multicolumn{2}{|l|}{ Normative commitment $(\alpha=.756, \mathrm{CR}=.70, \mathrm{AVE}=.624)$} \\
\hline I would feel guilty if I left Bank M now. & 0.722 \\
\hline This Bank deserves my loyalty. & 0.736 \\
\hline I would not leave Bank M right now because I have a sense of obligation to the people in it. & 0.756 \\
\hline \multicolumn{2}{|l|}{ Uncertainty $(\alpha=.812, \mathrm{CR}=.72, \mathrm{AVE}=.742)$} \\
\hline There is much uncertainty in Bank M right now. & 0.835 \\
\hline Many things seem unsettled at Bank M. & 0.893 \\
\hline If I think about Bank M, I feel much uncertainty. & 0.823 \\
\hline I cannot predict how things will go at that Bank M. & 0.736 \\
\hline \multicolumn{2}{|l|}{ Manipulation check (Cognitive and Affective appeal) } \\
\hline \multicolumn{2}{|l|}{ Cognitive appeal $(\alpha=.810, \mathrm{CR}=.82, \mathrm{AVE}=.722)$} \\
\hline This advertisement made me focus on my thoughts about the bank & 0.839 \\
\hline This advertisement was directed at making me think something about the bank & 0.795 \\
\hline \multicolumn{2}{|l|}{ Affective appeal $(\alpha=.837, \mathrm{CR}=.89, \mathrm{AVE}=.716)$} \\
\hline This advertisement made me focus on my feelings about the bank & 0.925 \\
\hline This advertisement is directed at making me feel something about the bank & 0.718 \\
\hline
\end{tabular}

Note: $\alpha=$ Cronbach's alpha, $\mathrm{CR}=$ Cronbach's reliability, $\mathrm{AVE}=$ average variance extracted

\section{Results}

\subsection{Measurement model}

We conducted a confirmatory factor analysis (CFA) to determine the convergent and discriminant using STATA 14.1. CFA results showed that the multiple-indicator model fit the data $(\chi 2 / d f=1.78, p<.001 ; \mathrm{RMSEA}=.025 ; \mathrm{TLI}=.92 ; \mathrm{CFI}=.95)$. Composite reliabilities (CR) ranged from .70 to .93, indicating adequate reliability of measurements. All factor loadings were .714 to .912 , greater than the .50 cut off (Brown, 2002). Results of the average variance extracted (AVE) estimations were .577 to .74 , higher than the .50 cut-off. These results satisfy the convergent validity (Farrell, 2010). See table 1 . Comparing results in Table 3 indicate that the square roots of the AVEs of the constructs (from .760 to .862) were greater than their corresponding correlations and the various correlation between two constructs are less than their respective reliability estimates, supporting discriminant validity (Farrell, 2010). 
A major problem of self-reported questionnaire is the issue of common method bias (CMB). To control for common method bias in the measurement model, the suggestions recommended by Podsakoff, MacKenzie, Lee, and Podsakoff (2003) using the unmeasured latent method factor technique were employed. Following the steps of Podsakoff et al. (2003), an unmeasured latent variable was created and loaded on each manifest variable to ascertain if the presence of the unmeasured latent variable affected factor loadings of each manifest variable on its respective latent constructs. Factor loadings obtained after common method bias was controlled for, was then compared to the factor loadings in the original sample. A change of more than 0.2 in the factor score was an indication of a significant change in the regression weight of the manifest variable when common method bias was controlled (Fuller, Simmering, Atinc, Atinc, \& Babin, 2016, p. 3195). No factor score had a change of more than 0.2 . Thus, we concluded that common method bias did not alter the validity of the study results. (See appendix for CMB results)

\subsection{Descriptive Statistics}

The correlation matrix is reported in Table 2. Means and standard deviations of factor scores are reported in Table 3. Manipulation check was conducted by comparing affective and cognitive trust levels for each ad. As it was planned, participants who viewed Affective ad reported a higher level of affective trust $(M=3.57, S D=0.65)$ than cognitive trust $(M$ $=2.99, S D=0.87)$, indicating statistically significant difference $(t=-3.343, p=.000)$. The manipulation for Cognitive ad was also successful. As it was planned, participants who viewed Cognitive ad reported a higher level of cognitive trust $(M=3.48$, $S D=0.68)$ than affective trust $(M=3.15, S D=0.6)$, indicating statistically significant difference $(t=3.632, p=.000)$.

Table 2

Zero-order correlations among study variables $(\mathrm{N}=254)$.

\begin{tabular}{|c|c|c|c|c|c|c|c|c|}
\hline & Variables & 1 & 2 & 3 & 4 & 5 & 6 & 7 \\
\hline 1 & Appeal & & & & & & & \\
\hline 2 & Future interaction & -0.17 & .823 & & & & & \\
\hline 3 & Affective trust & $.32 * * *$ & $.46^{* * *}$ & .760 & & & & \\
\hline 4 & Cognitive trust & $-.35^{* *}$ & $.61 * * *$ & 0.19 & .778 & & & \\
\hline 5 & Commitment & -0.19 & $.33 * * *$ & 0.17 & $.24 *$ & .790 & & \\
\hline 6 & Uncertainty & $.22 *$ & $-.33 * *$ & -0.14 & $-.38 * *$ & -0.19 & .861 & \\
\hline 7 & Attitude & -0.03 & $.62 * * *$ & $.45 * * *$ & $.39 * *$ & $.26^{*}$ & $-.57 * *$ & .862 \\
\hline
\end{tabular}

Note: Bold diagonal entries are the square root of AVE. $\mathrm{p}^{*}<.05, \mathrm{p}^{* *}<.01, \mathrm{p}^{* * *}<.001 ;$ two-tailed Test

Table 3

Sample means, and standard deviations using factor scores

\begin{tabular}{lllll}
\hline & \multicolumn{2}{l}{ Cognitive appeal } & \multicolumn{2}{l}{ Affective appeal } \\
\cline { 2 - 5 } & Mean & SD & Mean & SD \\
\hline Future interaction & 3.35 & 0.79 & 3.09 & 0.73 \\
Affective trust & 3.14 & 0.60 & 3.57 & 0.65 \\
Cognitive trust & 3.48 & 0.68 & 2.99 & 0.66 \\
Commitment & 2.70 & 0.58 & 2.45 & 0.70 \\
Uncertainty & 2.79 & 0.72 & 3.09 & 0.63 \\
Attitude & 4.51 & 0.96 & 4.45 & 0.99 \\
\hline
\end{tabular}

\subsection{Assessing Common Method Bias}

Structural equation modelling (SEM) was used to test research questions. H1 addressed the relationship between affective trust and attitude toward the bank. As illustrated in Figure 4, affective trust was significantly associated with attitude toward the bank $(\beta=0.426, p<0.01)$. H2 predicted the impacts of cognitive trust on attitude toward the bank. As expected, cognitive trust had a positive relationship with attitude toward the bank $(\beta=0.409, p<0.01)$. H3 stated that affective trust had an insignificant influence on the commitment to a bank, while H4 stated that cognitive trust positively influenced commitment. The result revealed that cognitive trust has a significant and positive relation to commitment $(\beta=0.21, p<0.01)$. On the other hand, affective trust showed an insignificant relationship with commitment. Results of H5 showed us that the relationship between affective trust and uncertainty are insignificant. H6 addressed the relationship of cognitive trust with uncertainty. The result showed significant negative relation between two $(\beta=-0.35, p<0.01)$. H7 examined the association between affective trust and anticipation of future interaction. Affective trust was positively associated with future interaction $(\beta=0.41$, $p<0.01)$. Finally, H8 was stated that cognitive trust positively influences future interaction expectations. Cognitive trust had a positive significant relationship with future interaction expectations, and it was higher comparing to affective trust $(\beta=0.58$, $p<0.01$ ). Overall, the model explains a significant portion of the variance of the endogenous variables: cognitive trust $61 \%$, affective trust $56 \%$, and the anticipation of future interactions $71 \%$, commitment $61 \%$ and uncertainty $60 \%$. It explains $34 \%$ of the variance of attractiveness, which is reasonable given the multiplicity of factors outside of the relationship that affects the attitude (Grewal, Cote, \& Baumgartner, 2004). Table 4 present the details of the effects of different factors. 
Table 4

The summary of examining different factors

\begin{tabular}{|c|c|c|c|c|c|}
\hline Items & & Constructs & $\mathrm{A}$ & $\mathrm{B}$ & A - B \\
\hline AFT1 & $\leftarrow$ & Affective trust & 0.940 & 0.923 & 0.017 \\
\hline AFT2 & $\leftarrow$ & Affective trust & 0.799 & 0.718 & 0.081 \\
\hline AFT3 & $\leftarrow$ & Affective trust & 0.760 & 0.922 & -0.162 \\
\hline COT1 & $\leftarrow$ & Cognitive trust & 0.756 & 0.652 & 0.104 \\
\hline COT2 & $\leftarrow$ & Cognitive trust & 0.802 & 0.845 & -0.043 \\
\hline COT3 & $\leftarrow$ & Cognitive trust & 0.834 & 0.809 & 0.025 \\
\hline ATT1 & $\leftarrow$ & Attitude & 0.955 & 0.922 & 0.033 \\
\hline ATT2 & $\leftarrow$ & Attitude & 0.902 & 0.855 & 0.047 \\
\hline ATT3 & $\leftarrow$ & Attitude & 0.669 & 0.561 & 0.108 \\
\hline MCC1 & $\leftarrow$ & Manipulation check Cognitive & 0.839 & 0.826 & 0.013 \\
\hline MCC2 & $\leftarrow$ & Manipulation check Cognitive & 0.795 & 0.777 & 0.018 \\
\hline MCA1 & $\leftarrow$ & Manipulation check Affective & 0.925 & 0.895 & 0.03 \\
\hline MCA2 & $\leftarrow$ & Manipulation check Affective & 0.718 & 0.738 & -0.02 \\
\hline AFI1 & $\leftarrow$ & Anticipation of future interactions & 0.822 & 0.76 & 0.062 \\
\hline AFI2 & $\leftarrow$ & Anticipation of future interactions & 0.883 & 0.906 & -0.023 \\
\hline AFI3 & $\leftarrow$ & Anticipation of future interactions & 0.894 & 0.841 & 0.053 \\
\hline UNC1 & $\leftarrow$ & Uncertainty & 0.835 & 0.855 & -0.02 \\
\hline UNC2 & $\leftarrow$ & Uncertainty & 0.893 & 0.872 & 0.021 \\
\hline UNC3 & $\leftarrow$ & Uncertainty & 0.823 & 0.821 & 0.002 \\
\hline UNC4 & $\leftarrow$ & Uncertainty & 0.736 & 0.726 & 0.01 \\
\hline COM1 & $\leftarrow$ & Commitment & 0.722 & 0.663 & 0.059 \\
\hline COM1 & $\leftarrow$ & Commitment & 0.736 & 0.726 & 0.01 \\
\hline COM1 & $\leftarrow$ & Commitment & 0.756 & 0.652 & 0.104 \\
\hline
\end{tabular}

Note: $\mathrm{A}=$ Factor Loadings without $\mathrm{CMB}$

$\mathrm{B}=$ Factor Loading with $\mathrm{CMB}$

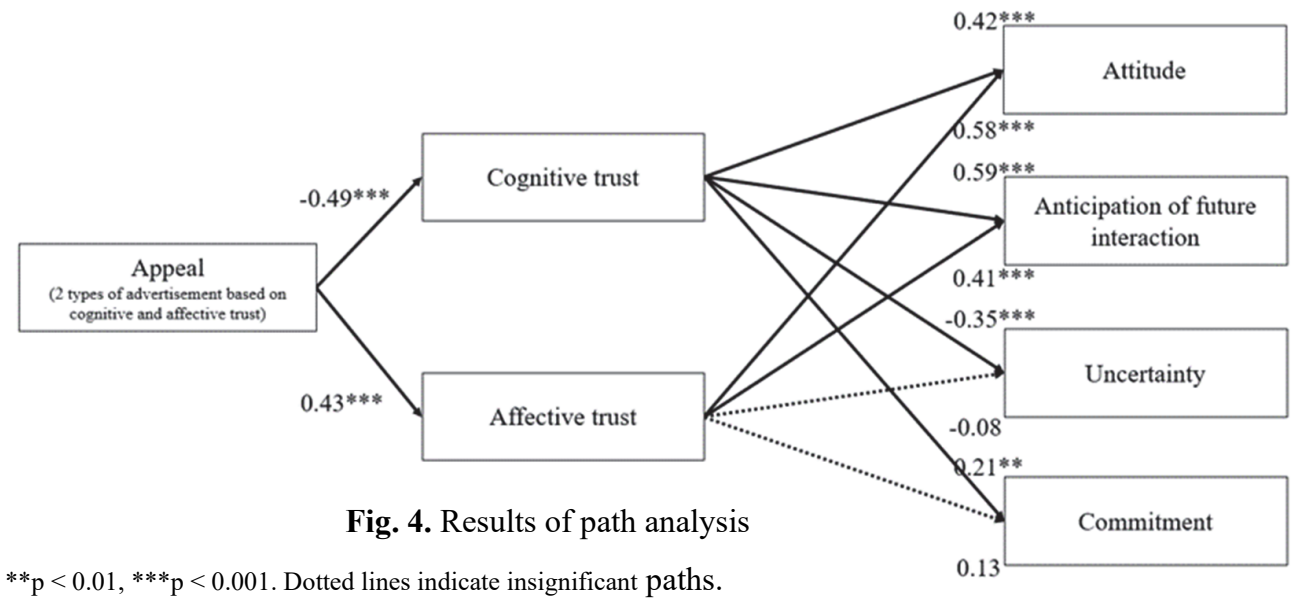

Note. $* * \mathrm{p}<0.01,{ }^{* * *} \mathrm{p}<0.001$. Dotted lines indicate insignificant paths.

\section{Discussion and conclusion}

The goal of the study was to examine the relationship between affective and cognitive trust in bank advertising. Precisely how do two types of advertisement affect the attitude toward a bank, anticipation of future interaction with a bank, commitment to the advertised bank and level of uncertainty customers may feel towards a bank. The study produces evidence supporting trust as having cognitive and affective dimensions in the advertisement of business-customer relations (Dowell et al., 2015). The two dimensions of trust are empirically distinguishable, and both dimensions of trust have unique characteristics (Johnson \& Grayson, 2005). The study indicates that customers are more drawn to affective ads. Applying an affective appeal (M=3.09) in marketing campaigns, according to the study, would have higher customer response compared to cognitive appeal (M= 2.79). Strengthening emotional bonds would lead to a significant willingness for future interaction. However, cognitive trust was a stronger predictor of anticipation towards future interactions with a bank than affective trust. It can be inferred that affective trust alone is not influential enough to affect one's overall willingness to interact in the future. Uncertainty and commitment had insignificant relationships with affective trust, suggesting that in order to decrease the feeling of uncertainty and increase the sense of obligation, it is better to appeal to cognitive trust of customers. Customer attitude toward banks was positively influenced by both affective and cognitive trust towards the bank. Previous research indicated a significant relationship between cognitive trust and commitment (Casalo et al., 2007; Colquitt et al., 2012; Erdem \& Ozen, 2003; Erkmen \& Hancer, 2015). Affective trust was reported in some studies to have weak significant relationships (Casalo et al., 2007; Erkmen \& Hancer, 2015) and insignificant relationship towards commitment (Colquitt et al., 2012). In the current study, cognitive trust had a significant relationship with commitment, while affective trust has no significant relationship with commitment. Both trust dimensions are essential to building general trust. Johnson and Grayson (2005) concluded in their study that multidimensional conceptualisation may be fruitful for exploring the managerial benefits of trust. Roy, Devlin, and 
Sekhon (2015) found that some customers value trust in their banks more than higher returns on their investments. The finding that affective trust significantly contributes to attitude and future interaction in the frame of bank advertising opens new doors to attract clients, especially in the field of intense competition. Use of cognitive trust appeals in advertising alone pushes consumers to consider alternative suppliers for better prices than that of their current banks. Ignoring the affective dimension in bank trust could, in the long run, influence customers to choose alternative banking or even non-bank institutions they trust (Bilton, 2016). For a bank to ensure retention of customers, the combination of affective and cognitive trust is needed, as focus on issues such as price and interest rates alone pushes clients to consider alternatives constantly.

\section{Theoretical implications}

To the best of our knowledge, no study has empirically examined the role of affective trust together with cognitive trust in bank advertising. In traditional bank marketing, cognitive trust related values such as reputation, history, overall presence in a particular area have been heavily focused. The study successfully demonstrates that attitude towards a bank and the willingness to engage in future interactions with a bank are influenced by cognitive and affective trust. The findings in this study contribute to the literature in bank marketing, regarding the effects of affective and cognitive trust dimensions on consumers. Affective and cognitive trust in general marketing literature is analysed mostly in interpersonal relationships such as the relationship of customers with workers, managers or employees with supervisors (Johnson \& Grayson, 2005). This study expands the scope of the theoretical conceptualisation of cognitive and affective trust into a new realm and further provides the empirical evidence showing the significant effect of both types of trust

\section{Practical implications}

The study suggests practical implications for marketing practitioners, entrepreneurs, and managers. Findings suggest that approaching different trust types is essential in bank marketing. Although the context of the study was about banks, it provides useful information for business to consumer communication in general. Trust building is so central in communication with consumers and needed in fields such as insurance, architecture, engineering, medical offices, advocacy, and advisory roles. Failing to build trust with customers would mean a significant loss of customers because trust helps the business to overcome situations where the amount of necessary knowledge is insufficient. This study presents one of the first studies testing two different types of trust in the relationship between finance intuitions and consumers. The study directly sends a message to entrepreneurs, managers, and retail owners that emotional attachment with your clients adds excellent value to the business. Affect, and cognitive trust plays a significant role, especially within the marketing industry in attracting customers to their banks or business firm. Trust facilities relationship processes that have a direct impact on economic outcomes (Bricci, Fragata, \& Antunes, 2016).

\section{Limitations and directions for future studies}

In developing economies, there is a generally low level of trust towards banks (Malaquias \& Hwang, 2016); hence people might be more sensitised to cognitive trust in order to reduce uncertainty on whether the bank is capable enough to handle their accounts. The relationship of the participants and the bank was fictional; the advertisement itself was not representing an actual bank. In virtual relationships, it is hard to actualise the feeling of obligation. In comparison, other studies referenced here (Colquitt et al., 2012; Johnson \& Grayson, 2005) were analysing real business relationships between customers and business entities, where certain feelings of obligation were built upon previous interaction. Further analysis is needed to find out the relationship between variables in real business cases. The study tested the effect of trust in the bank marketing context. More studies should be conducted to test if what was found in this study holds in other contexts where trust-building is essential. For example, insurance companies, architecture, and engineering, medical offices, advocacy. Every field where business interacts with customers' affective and cognitive trust could test and the current study can be applied. In that way, the applicability of the current study could be expanded to new fields.

\section{Conclusion}

Trust within the financial sector is crucial in enabling the full functioning of the bank system. Attaining and maintaining the trust of customers is very crucial. Trust dimensions can be distinguished and function separately, but it is suggested to use a combination of cognitive and affective trust to achieve better effects. The combination of affective and cognitive trust in bank advertisement helps ensure customer lockdown. Competence, ability, and credibility are vital in achieving higher customer trust, but these cognitive-based variants coerce the need to consider alternatives, to which a sense of affective belonging can counter to retain customers and promote trust.

\section{Acknowledgment}

The third authors are grateful to the Applied Science Private University, Amman, Jordan for the financial support granted to this research project.

\section{References}

Acar, M., \& Temiz, H. (2017). Advertising effectiveness on financial performance of banking sector: Turkey case. International Journal of Bank Marketing, 35(4), 649-661. 
Akrout, H., Diallo, M. F., Akrout, W., \& Chandon, J.-L. (2016). Affective trust in buyer-seller relationships: a twodimensional scale. Journal of Business \& Industrial Marketing, 31(2), 260-273.

Alsajjan, B., \& Dennis, C. (2010). Internet banking acceptance model: Cross-market examination. Journal of Business Research, 63(9-10), 957-963. doi:10.1016/j.jbusres.2008.12.014

Amoako, G. K., Anabila, P., Effah, E. A., \& Kumi, D. K. (2017). Mediation role of brand preference on bank advertising and customer loyalty. International Journal of Bank Marketing, 35(6), 983-996.

Bachnik, K., \& Nowacki, R. (2018). How to Build Consumer Trust: Socially Responsible or Controversial Advertising. Sustainability, 10, 2173.

Banks, D. T., Hutchinson, J. W., \& Meyer, R. J. (2002). Reputation in marketing channels: Repeated-transactions bargaining with two-sided uncertainty. Marketing Science, 21(3), 251-272.

Bilton, S. (2016). Satisfied, loyal.... and leaving? The effect of trust and commitment on consumer satisfaction and loyalty: a study of a non-bank deposit taker and retail banks in New Zealand.

Bricci, L., Fragata, A., \& Antunes, J. (2016). The effects of trust, commitment and satisfaction on customer loyalty in the distribution sector. Journal of Economics, Business and Management, 4(2), 173-177.

Brown, J. D. (2002). The Cronbach alpha reliability estimate. JALT Testing \& Evaluation SIG Newsletter, 6(1).

Casalo, L. V., Flavián, C., \& Guinalíu, M. (2007). The influence of satisfaction, perceived reputation and trust on a consumer's commitment to a website. Journal of Marketing Communications, 13(1), 1-17.

Colquitt, J. A., LePine, J. A., Piccolo, R. F., Zapata, C. P., \& Rich, B. L. (2012). Explaining the justice-performance relationship: Trust as exchange deepener or trust as uncertainty reducer? Journal of applied psychology, $97(1), 1$.

Cooper, D. R., \& Schindler, P. S. (2003). Business Research Methods. McGraw-Hill: New York. In.

Darfah, E. F. (2019). BoG shuts down 347 insolvent microfinance companies. Retrieved from Graphic Online website: https://www.graphic.com.gh/business/business-news/ghana-news-bog-shuts-down-192-insolvent-microfinancecompanies.html

Dowell, D., Morrison, M., \& Heffernan, T. (2015). The changing importance of affective trust and cognitive trust across the relationship lifecycle: A study of business-to-business relationships. Industrial Marketing Management, 44, 119-130.

Drolet, A., \& Aaker, J. (2002). Off-target? Changing cognitive-based attitudes. Journal of consumer psychology, 12(1), 5968.

Eckford, R. D., \& Barnett, D. L. (2016). Comparing paper-and-pencil and Internet survey methods conducted in a combatdeployed environment. Military Psychology, 28(4), 209-225.

Ennew, C., \& Sekhon, H. (2007). Measuring trust in financial services: the Trust Index. Consumer Policy Review, 17, $62-68$.

Erdem, F., \& Ozen, J. (2003). Cognitive and affective dimensions of trust in developing team performance. Team Performance Management: An International Journal, 9(5/6), 131-135.

Erkmen, E., \& Hancer, M. (2015). Linking brand commitment and brand citizenship behaviors of airline employees:"The role of trust". Journal of Air Transport Management, 42, 47-54.

Farrell, A. M. (2010). Insufficient discriminant validity: A comment on Bove, Pervan, Beatty, and Shiu (2009). Journal of Business Research, 63(3), 324-327.

Flavián, C., Guinalíu, M., \& Gurrea, R. (2006). The role played by perceived usability, satisfaction and consumer trust on website loyalty. Information \& Management, 43(1), 1-14. doi:10.1016/j.im.2005.01.002

Fuller, C. M., Simmering, M. J., Atinc, G., Atinc, Y., \& Babin, B. J. (2016). Common methods variance detection in business research. Journal of Business Research, 69(8), 3192-3198.

Gambetta, D. (1988). Trust: Making and breaking cooperative relations: B. Blackwell New York, NY.

Gefen, D., Karahanna, E., \& Straub, D. (2003). Trust and TAM in online shopping: An integrated model. Mis Quarterly, 27(1), 51-90. doi:10.2307/30036519

Gill, A. S., Flaschner, A. B., \& Shachar, M. (2006). Factors that affect the trust of business clients in their banks. International Journal of Bank Marketing, 24(6), 384-405.

Grayson, K., Johnson, D., \& Chen, D.-F. R. (2008). Is firm trust essential in a trusted environment? How trust in the business context influences customers. Journal of Marketing Research, 45(2), 241-256.

Grewal, R., Cote, J. A., \& Baumgartner, H. (2004). Multicollinearity and measurement error in structural equation models: Implications for theory testing. Marketing Science, 23(4), 519-529.

Guiso, L. (2010). A Trist-Driven Financial Crisis. Implications for the Future of Financial Markets.

Ha, B.-C., Park, Y.-K., \& Cho, S. (2011). Suppliers' affective trust and trust in competency in buyers: Its effect on collaboration and logistics efficiency. International Journal of Operations \& Production Management, 31(1), 56-77.

Ha, V. (2020). The effects of attitude, trust and switching cost on loyalty in commercial banks in Ho Minh City. Accounting, $6(2), 151-160$.

Hansen, M. H., Morrow Jr, J. L., \& Batista, J. C. (2002). The impact of trust on cooperative membership retention, performance, and satisfaction: an exploratory study. The International Food and Agribusiness Management Review, 5(1), 41-59.

Howard, D. J., \& Kerin, R. A. (2004). The effects of personalized product recommendations on advertisement response rates: The "try this. It works!" technique. Journal of consumer psychology, 14(3), 271-279.

Hultén, B. (2007). Customer segmentation: The concepts of trust, commitment and relationships. Journal of Targeting, Measurement and Analysis for Marketing, 15(4), 256-269.

Huq, M., \& Tribe, M. (2018). Banking and Finance. In The Economy of Ghana (pp. 189-219): Springer. 
Insko, C. A., Schopler, J., Gaertner, L., Wildschut, T., Kozar, R., Pinter, B., . . Montoya, M. R. (2001). Interindividualintergroup discontinuity reduction through the anticipation of future interaction. Journal of Personality and Social Psychology, 80(1), 95.

Johnson, D., \& Grayson, K. (2005). Cognitive and affective trust in service relationships. Journal of Business Research, 58(4), 500-507.

Kaushik, A. K., Mohan, G., \& Kumar, V. (2020). Examining the Antecedents and Consequences of Customers' Trust Toward Mobile Retail Apps in India. Journal of Internet Commerce, 19(1), 1-31. doi:10.1080/15332861.2019.1686333

Kosiba, J. P., Boateng, H., Okoe, A. F., \& Hinson, R. (2020). Trust and customer engagement in the banking sector in Ghana. The Service Industries Journal, 40(13-14), 960-973.

Lantieri, T., \& Chiagouris, L. (2009). Brand trust in an age without trust: expert opinions. Journal of Consumer Marketing, 26(2), 78-86.

Macintosh, G., \& Lockshin, L. S. (1997). Retail relationships and store loyalty: A multi-level perspective. International Journal of Research in Marketing, 14(5), 487-497. doi:10.1016/S0167-8116(97)00030-X

Malaquias, R. F., \& Hwang, Y. (2016). An empirical study on trust in mobile banking: A developing country perspective. Computers in Human Behavior, 54, 453-461.

McAllister, D. J. (1995). Affect-and cognition-based trust as foundations for interpersonal cooperation in organizations. Academy of management journal, 38(1), 24-59.

McCole, P., Ramsey, E., \& Williams, J. (2010). Trust considerations on attitudes towards online purchasing: The moderating effect of privacy and security concerns. Journal of Business Research, 63(9-10), 1018-1024.

Miranda, R., \& Klement, J. (2009). Authentic trust in modern business. The Journal of Wealth Management, 11(4), $29-47$.

Morgan, R. M., \& Hunt, S. D. (1994). The commitment-trust theory of relationship marketing. Journal of Marketing, 58(3), 20-38.

Mukherjee, A., \& Nath, P. (2003). A model of trust in online relationship banking. International Journal of Bank Marketing, $21(1), 5-15$.

Nguyen, O. T. (2020). Factors affecting the intention to use digital banking in Vietnam. Journal of Asian Finance, Economics and Business, 7(3), 303-310. doi:10.13106/jafeb.2020.vol7.no3.303

Opoku, D. M. (2016). Parliament passes Deposit Protection Bill. http://citifmonline.com/2016/07/04/parliament-passesdeposit-protection-bill/

Parayitam, S., \& Dooley, R. S. (2009). The interplay between cognitive-and affective conflict and cognition-and affect-based trust in influencing decision outcomes. Journal of Business Research, 62(8), 789-796.

Pickton, D., \& Broderick, A. (2005). Integrated marketing communications (2nd ed.). United Kingdom: Pearson Education.

Podsakoff, P. M., MacKenzie, S. B., Lee, J.-Y., \& Podsakoff, N. P. (2003). Common method biases in behavioral research: A critical review of the literature and recommended remedies. Journal of Applied Psychology, 88(5), 879.

Rajavi, K., Kushwaha, T., \& Steenkamp, J. B. E. (2019). In brands we trust? A multicategory, multicountry investigation of sensitivity of consumers' trust in brands to marketing-mix ctivities. Journal of Consumer Research, 46(4), 651-670.

Roy, S. K., Devlin, J. F., \& Sekhon, H. (2015). The impact of fairness on trustworthiness and trust in banking. Journal of Marketing Management, 31(9-10), 996-1017.

Sapienza, P., \& Zingales, L. (2012). A trust crisis. International Review of Finance, 12(2), 123-131.

Schultz, D. (2016). The Future of Advertising or Whatever We're Going to Call It. Journal of Advertising, 45(3), $276-285$.

Sharif, K. J., Kalafatis, S. P., \& Samouel, P. (2005). Cognitive and behavioural determinants of trust in small and mediumsized enterprises. Journal of Small Business and Enterprise Development, 12(3), 409-421.

Smyth, H., Gustafsson, M., \& Ganskau, E. (2010). The value of trust in project business. International Journal of Project Management, 28(2), 117-129.

Sundin, K., \& Nordin, F. (2013). Customer satisfaction in the Swedish financial sector. (Master's), Umeå Universitet

Thorson, E., \& Rodgers, S. (2012). What Does "Theories of Advertising" Mean? In S. Rodgers \& E. Thorson (Eds.), Advertising theory. New York: Routledge.

Uslaner, E. M. (2010). Trust and the economic crisis of 2008. Corporate Reputation Review, 13(2), 110-123.

van Esterik-Plasmeijer, P. W., \& van Raaij, W. F. (2017). Banking system trust, bank trust, and bank loyalty. International Journal of Bank Marketing, 35(1), 97-111.

Wälti, S. (2012). Trust no more? The impact of the crisis on citizens' trust in central banks. Journal of International Money and Finance, 31(3), 593-605.

World, B. (2017). Ghana's Microfinance Sector: Challenges, Risks and Recommendations.

Yang, J., Mossholder, K. W., \& Peng, T. (2009). Supervisory procedural justice effects: The mediating roles of cognitive and affective trust. The Leadership Quarterly, 20(2), 143-154.

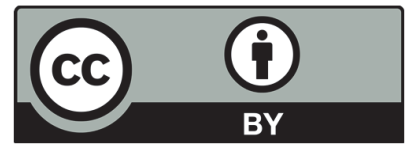

(C) 2021 by the authors; licensee Growing Science, Canada. This is an open access article distributed under the terms and conditions of the Creative Commons Attribution (CC-BY) license (http://creativecommons.org/licenses/by/4.0/). 